OPEN ACCESS

Citation: Mauro Bertolotti, Claudia Leone, Patrizia Catellani (2021) Think different? Populist attitudes and their consequences on vote behaviour in the 2016 and 2020 italian constitutional referenda. Quaderni dell'Osservatorio elettorale - Italian Journal of Electoral Studies 84(2): 65-78. doi: 10.36253/qoe10710

Received: March 20, 2021

Accepted: October 21, 2021

Published: October 25, 2021

Copyright:@2021 MauroBertolotti, Claudia Leone, Patrizia Catellani. This is an open access, peer-reviewed article published by Firenze University Press (http://www.fupress.com/qoe) and distributed under the terms of the Creative Commons Attribution License, which permits unrestricted use, distribution, and reproduction in any medium, provided the original author and source are credited.

Data Availability Statement: All relevant data are within the paper and its Supporting Information files.

Competing Interests: The Author(s) declare(s) no conflict of interest.

Orcid

MB: 0000-0003-0079-1642

PC: 0000-0002-7195-8967

\section{Think different? Populist attitudes and their consequences on vote behaviour in the 2016 and 2020 italian constitutional referenda}

\author{
Mauro Bertolotti ${ }^{1, \star}$, Claudia Leone $^{2}$, Patrizia Catellani ${ }^{3}$ \\ 1,2,3 Department of Psychology, Catholic University of Milan \\ ${ }^{\star}$ Corresponding author. Email: mauro.bertolotti@unicatt.it
}

\begin{abstract}
Following the rise of populist parties and leaders in the last decade, research has extensively investigated the political and economic factors that have driven some voters towards populism. Less research has been devoted to the individual psychological factors associated with populist attitudes, and to how those can influence political decisions, such as vote choice in an election or referendum. In this study, we analysed data from the 2016 and 2020 ITANES panel surveys, where populist attitudes were measured by a 6 -item scale. Findings indicate that populist attitudes were associated with relevant psychosocial factors, such as nationalism, political efficacy, and conspiracist beliefs. Populist attitudes in turn explained part of the variance in vote choice at both referenda, after controlling for the evaluation of the reform and political orientation. Furthermore, we found that voters with strong populist attitudes were more likely to engage in motivated reasoning in the form of the biased evaluation of the foreseeability of the referendum results, making simplified and self-reassuring evaluations aligned with their vote choice. The discussion focuses on how populism as a political phenomenon can be rooted in relevant individual differences in the psychological features of voters.
\end{abstract}

Keywords: populism, referendum, hindsight bias, motivated reasoning.

The focus of the present paper is to investigate the role of populism in the two electoral turning points represented by the 2016 and 2016 Italian constitutional referenda, and to understand the key characteristics of populist voters across time and political developments, by highlighting the social psychological and cognitive features associated with voters' populist attitudes. By analysing data collected in correspondence with the two referenda by the ITANES panel survey, we investigated to what extent economic and political dissatisfaction, nationalism, political orientation, and conspiracy theory beliefs were associated with populist attitudes. We then tested our hypothesis that populist attitudes were a significant factor in vote choice at both elections, despite the different content of the two constitutional reform proposals, and the different political alignments occurring in the two electoral scenarios. Finally, we investigated for the first time the association 
between populist attitudes and a cognitive bias, namely the hindsight bias, in order to test our hypothesis that populist voters differed from other voters not only in their vote choice at the 2020 referendum, but also in the way they retrospectively evaluated its outcome.

\section{DEFINING AND MEASURING POPULISM}

Defining populism has been a central issue in the recent academic debate. Populism adapts and changes in relation to the context in which it is expressed, being "a thin-centred ideology that considers society to be ultimately separated into two homogeneous and antagonistic groups, 'the pure people' versus 'the corrupt élite', and which argues that politics should be an expression of the volonté générale (general will) of the people" (Mudde, 2007, p. 23). This definition covers two main themes of populism: one is its mutable relationship with ideology, and the other is the dualism of people versus élites as the cornerstone of its worldview and rhetoric, where the people are the oppressed and the élites are the oppressors.

As to the relationship between populism and ideology, over time populism has been associated with cultural and economic positions related to both the traditional right (e.g., nativism) and the traditional left (e.g., socialism), and populist movements have positioned themselves across the political spectrum, and sometimes outside it (Mudde \& Rovira Kaltwasser, 2013).

As to the dualism of the people versus the élites, identification with a pure people is central in the creation and definition of populist movements (Mayer, Kaymak, \& Justice, 2000), in contraposition with a corrupt élite. This in-group vs. out-group distinction is routinely used by populist leaders to provide followers with a distinct yet inclusive identity, which is key to the building and polarisation of consensus.

In parallel with the theoretical definition of populism, based on the analysis of populist leaders' rhetoric, party manifestos and party platforms (Hawkins, 2009; Pauwels, 2011; Rooduijn, de Lange \& van der Brug, 2014; Rooduijn \& Pauwels, 2011), there have been several attempts to develop an empirical measure of citizens' support for populist ideas and beliefs, and delineate the characteristics of populist voters, identifying the features that distinguish them from the supporters of parties along the traditional political spectrum.

Early attempts (Elchardus \& Spruyt, 2012; Hawkins, Riding \& Mudde, 2012; Stanley, 2011) yielded mixed results in terms of measurement accuracy and predictive power (e.g., the association with support for popu- list parties). Thereafter, Akkerman, Mudde, and Zaslove (2014) developed a measure of populism as an attitude. A sample of 586 Dutch respondents were asked to report their agreement with 14 statements, using a 5-point Likert scale ranging from 1 (I very much disagree) to 5 (I very much agree). After conducting a principal component analysis, Akkerman and colleagues (2014) selected 7 items to form a scale of populist attitudes. These items include statements referring to popular sovereignty (e.g., "The people, and not politicians, should make our most important policy decisions"), the contraposition between the people and the élites (e.g., "The political differences between the elite and the people are larger than the differences among the people"), and Manichean antagonism to an evil political élite (e.g., "Politics is ultimately a struggle between good and evil"). Participants' scores on this scale were negatively correlated with measures of elitism and pluralism (Hawkins et al., 2012), and they were significantly higher among voters of left- and right-wing populist parties, as compared to voters of mainstream left- and right-wing parties. As the measure includes multiple dimensions, different approaches to its scoring have been proposed. Whereas most studies simply averaged the item scores into a single score representing a global indicator of participants' populist attitudes, others (Wuttke, Schimpf \& Schoen, 2020) argued that a non-compensatory scoring strategy may better reflect individual's attitudes along the different dimensions of the construct, identifying as populist only those who score high in each and every dimension of the populist attitudes.

In addition to the Netherlands (Geurking, Zaslove, Sluiter \& Jacobs, 2020), the scale developed by Akkerman and colleagues (2014) has been widely employed in studies conducted in several other countries, such as Belgium (Spruyt, Keppens \& Van Droogenbroeck 2016), Chile (Hawkins \& Rovira Kaltwasser 2014), France (Vasilopoulos \& Jost, 2020), Switzerland (Schulz et al., 2018), the U.S.A. (Oliver \& Rahn 2016), and Italy (Cremonesi, 2019). The items included in the ITANES 2020 survey, and used in this study, were also based on this scale.

\section{THE PSYCHOSOCIAL ANTECEDENTS OF POPULISM}

Besides its definition and measurement, another main area of research on populism dealt with its roots in citizens' political, economic, and social characteristics. A first cluster of studies has explored the so-called economic anxiety hypothesis (Hernandez \& Kriesi, 2015; Rooduijn \& Burgoon, 2018), according to which populism is related with negative economic conditions, such as those 
arising from global financial crises. These generate economic insecurity and dissatisfaction among many citizens, and the difficult handling of these economic conditions further reduces citizens' trust in incumbent politicians, whether they are left- or right-wing oriented, and in the political system as a whole (Algan, Guriev, Papaioannou \& Passari, 2017). This process creates fertile ground for the growth of populist parties, which tend to be outside traditional parliamentary majorities, in a position that allows them to blame the "corrupted élites" for unsatisfactory economic performances (Rooduijn, 2018), as well as to make generous and reassuring promises to the economically distressed voters.

Based on these assumptions, some studies have investigated whether individual perceptions of the economic outlook and insecurity are associated with support for populist parties and populist attitudes (Rothwell \& Diego-Rosell, 2016). These studies, however, found only weak evidence of greater populism among individuals from low-income households than among individuals from more affluent backgrounds. Research in the area of political psychology analysed low external political efficacy, that is the perception of politicians and the political system not caring about citizens' opinions, as a potential mediating factor between negative economic evaluations and support for populist leaders and movements (Rooduijn, Van Der Brug \& De Lange, 2016). This concept is also clearly related with the more general notion of political discontent (Passarelli \& Tuorto, 2018; Van der Brug, 2003) that comes from the weak presence and the inconsistent responsiveness of political institutions, causing frustration and a loss of trust in traditional political parties.

Another set of studies have explored the so-called cultural backlash hypothesis (Inglehart \& Norris, 2016), according to which populist attitudes are associated with the perception of a changing cultural (rather than economic) outlook, and the experience of citizens feeling "strangers in their own land" (Eatwell \& Goodwin, 2018; Inglehart \& Norris 2016). In this case, populist attitudes are seen as a form of individual reactance to some cultural trends which have become mainstream in the latter part of the $20^{\text {th }}$ century, such as secularisation, globalisation, and multiculturalism. Whereas both centre-left and centre-right parties substantially accept these trends and incorporate them in their political agendas, populist leaders and parties propose themselves as defenders of traditional values, local economic interests, and native populations, adopting anti-diversity, anti-European (Bellucci \& Serricchio, 2016), and anti-immigrant rhetoric. Immigration, seen as a threat to both economic security and cultural integrity (Stephan, Ybarra \& Morrison, 2016), has been especially focused on by populist move- ments (Mudde, 1999; Pettigrew, 2016), and several studies have identified significant associations between populism, ethnonationalism, and negative attitudes towards immigrants (e.g., Marchlewska et al., 2018).

Research in the area of political psychology has further investigated the implications of the cultural backlash hypothesis, looking for the psychosocial dimensions associated with ethno-nationalism and support for populist parties. This line of research has identified relative deprivation and collective narcissism as two main psychosocial factors underlying populist attitudes. Relative deprivation has been long studied in social psychology in the context of intergroup conflict (Walker \& Pettigrew, 1984) and collective action. It is the belief that one's in-group receives less than rival out-groups, generating feelings of injustice and resentment towards said out-groups, not because of their objective material wealth, but because of the perceived uneven distribution of resources and status. Relative deprivation often applies to ethnic or immigrant minorities, which are targeted for the perceived undeserved benefits they receive from the States. In a study with Belgian participants, relative deprivation was found to be positively associated with populist attitudes (Elchardus \& Spruyt, 2016). Similarly, in a study conducted in the USA (Marchlewska, et al., 2018), relative deprivation was found to be a positive predictor of vote for a populist candidate (i.e., Donald Trump). The same study also found an association between support for populist candidates and collective narcissism, defined as an unrealistic belief in one's ingroup's greatness, contingent on external validation (de Zavala, Cichocka, Eidelson \& Jayawickreme, 2009).

In our study, we considered a range of potential psychosocial antecedents of populism, in order to assess their association with populist attitudes measured in the ITANES 2020 survey. In particular, we included in our analysis participants' perception of the economy (both at the national and at the household level), and measures of internal and external political efficacy, to test the role of economic anxiety and political distrust in the development of populist attitudes. We then included two measures of participants' attitudes towards two key issues related to nationalism, namely immigration and membership in the European Union, to test their association with populist attitudes, as hypothesized by the cultural backlash hypothesis.

\section{POPULISM, CONSPIRACISM AND COGNITIVE BIASES}

In addition to the economic, political, and psychosocial factors discussed above, some research sug- 
gests that populism may be also associated with certain shared beliefs, and the individual cognitive processes fostering them.

There is growing evidence of, and concern for, populist movements' and leaders' use of conspiracy theories to gain consensus (Castanho-Silva, Vegetti \& Littvay, 2017; Hameleers, 2020; van Prooijen \& Douglas, 2018). Recent research has therefore started investigating whether supporters of populist parties are particularly attracted by this kind of narrations (Enders \& Smallpage, 2019), and whether these narrations are particularly persuasive for individuals with certain worldviews and cognitive styles. Conspiracy theories are explanations of political or historical events that go against those commonly accepted by the political and media establishment, and argue for the existence of vast and powerful machinations that control social, political, and economic events in order to oppress the population, or parts of it (Douglas, Sutton \& Chichoka, 2017). These elements of conspiracy theories appear to fit with populists' Manichaeism (Hawkins, 2009), and political and social distrust (Goertzel, 1994), as they reinforce the idea of the people being a candid and unaware victim of the deeds of an evil cabal of politicians and businessmen.

Research on the link between conspiracist beliefs and populist attitudes provides some insight into the tendency of populist voters to deviate from strictly objective and fact-based evaluations, in favour of simplistic narratives that are consistent with their prior beliefs (Catellani, 2020; Fiedler, 2021), thus suggesting that endorsement of conspiracist beliefs may be the result of motivated reasoning (Taber \& Lodge, 2006). Past research on politically motivated reasoning (Jost, Hennes, \& Lavine, 2013), in particular, has already shown that such phenomenon is present in voters throughout the political spectrum (Achen \& Bartels, 2016; Flynn, Nyhan \& Reifler, 2017; Kahan, 2016; Leeper \& Slothuus, 2014; Lodge \& Taber, 2013), and associated with certain individual characteristics, such as high levels of dogmatism and intolerance for ambiguity (Federico \& Malka, 2018; Jost, 2017; Jost et al., 2013). These features, which have been attributed in the past to certain political groups such as extremists and conservatives, appear to be relevant also in defining populist voters. Therefore, it is possible that populist voters would frequently incur in cognitive biases and motivated reasoning when processing political information.

We focus here on one specific bias, the so-called hindsight bias (Fischhoff, 1975), which is known to commonly occur in political judgements, such as when discussing the outcome of an election (Bertolotti \& Catellani, 2021; Blank, Fischer \& Erdfelder, 2003). Generally speaking, the hindsight bias is the tendency to retrospectively overestimate the likelihood of an outcome (Roese \& Vohs, 2012), and it is experienced as the failure to correctly recollect past inaccurate predictions (the memory distortion component), the tendency to perceive the actual outcome as unavoidable (the inevitability component), and to overstate one's ability to predict it (the retrospective foreseeability component). This latter component has been found to be particularly affected by motivational factors, such as the desire to perceive the world as ordered and controllable (Markman \& Tetlock, 2000; McGraw \& Tetlock, 2005; Thompson, Armstrong \& Thomas, 1998) and the desire to reduce ambiguity by reaching a sense of cognitive closure (Kruglanski \& Webster, 1996), both of which are related to the already mentioned intolerance of ambiguity. Furthermore, research has found retrospective foreseeability to be related also to self-presentation concerns, that is the desire to put oneself (and one's relevant group, based on political, social, or national identification) in a positive light. As foresight and shrewdness are usually considered desirable traits to possess, individuals are inclined to claim that they had made correct predictions regarding the outcome of events (including elections), even when this was not actually the case (Mark \& Mellor, 1991; Sedikides \& Greg, 2008). They are also inclined to exaggerate or downplay the foreseeability of events depending on how they reflect on the image of their relevant group, such as their political party or movement (Louie, Curren, \& Harich, 2000; Pezzo, 2011). When an event is deemed positive, as in the case of an electoral victory or a good performance of one's preferred party, individuals are more likely to consider it foreseeable. This biased evaluation appears to be mainly driven by an affective reaction to the outcome, namely, satisfaction (Bertolotti \& Catellani, 2021). When, conversely, an event is deemed negative, as in the case of a political defeat or a poor electoral performance, individuals tend to distance themselves from it, deeming it unpredictable and unforeseeable (Louie, 1999; Mark \& Mellor, 1991; Pezzo \& Pezzo, 2007).

In this paper, we moved from the assumption that individuals with strong populist attitudes would be more prone than others to incur in this type of hindsight bias, and to accommodate their retrospective evaluations of referendum outcomes based on how they reflected on their own position, thus evaluating a victory as highly foreseeable, and a defeat as surprising. This result would be consistent with populists' preference for a simplified and extremized representation of reality over a more complex and nuanced one, as well as with their heightened need for confirmation of individual- and group- 
level value, as indicated by research on populists' collective narcissism and relative deprivation (Marchlewska, et al., 2018; Elchardus \& Spruyt, 2016).

\section{RESEARCH HYPOTHESES}

Using ITANES panel data from the 2016 and 2020 constitutional referenda, we investigated the antecedents of populist attitudes, as well as the consequences of those attitudes on vote choice and on the evaluation of the electoral results.

First, based on previous research on the economic, political, and psychological factors associated with populism and support for populist leaders and parties, we tested the strength and direction of the association between populist attitudes and economic perceptions (Rothwell \& Diego-Rosell, 2016; Rooduijn \& Burgoon, 2018), political efficacy (Algan et al., 2017) and attitudes, in particular regarding EU membership and immigration (Inglehart \& Norris, 2016; Stephan, Ybarra \& Morrison, 2016), and political orientation (Geurkink, et al., 2020). We also included a relevant psychosocial factor in our model, namely belief in conspiracy theories (Castanho-Silva, et al., 2017). We therefore formulated the following set of hypotheses.

Populist attitudes are negatively associated with participants' evaluation of the economic situation (H1a), political efficacy (H1b), and attitudes towards the EU (H1c) and immigration (H1d), whereas they are positively associated with right-wing political orientation (H1e) and belief in conspiracy theories (H1f).

Second, we explored the role of populist attitudes in vote choice at the two constitutional referenda. Past research on vote choice on specific topics or issues has argued that when citizens struggle to fully understand the object of the ballot (De Angelis, Colombo, \& Morisi, 2020), they look for heuristic cues that may help their decision-making task (Lau \& Redlawsk, 2001; Lupia, McCubbins, \& Popkin, 2000), such as partisan cues. We proposed that, in addition to the well-known and studied cues related to political orientation (Colombo \& Kriesi, 2017), citizens may also rely on their populist attitudes when deliberating on political matters, such as in the case of a constitutional referendum. In particular, proposals presented as simple and clear-cut positions on political issues may resonate with the highly polarized and simplistic approach typical of populism. We therefore formulated the following hypotheses.

Populist attitudes are an independent predictor of vote choice against the 2016 constitutional reform (H2a) and in favour of the 2020 constitutional reform (H2b), in addition to, and independent from the evaluation of the respective reforms and political orientation.

Third, we further investigated how populist attitudes influenced not only political decisions, but also the way citizens think of political events, such as the outcome of an election. In particular, we tested whether and how populist attitudes were associated with hindsight bias in the evaluation of the foreseeability of the 2020 referendum outcome. Past research (Bertolotti \& Catellani, 2021) indicates that citizens' satisfaction with an electoral outcome can subtly bias their retrospective evaluations of the event, making desired outcomes appear more foreseeable than undesired ones. Since populist citizens appear to be easily prone to simplified and biased political evaluations, we expected them to experience stronger hindsight bias in the evaluation of the foreseeability of electoral results, as well. We therefore formulated the following hypotheses.

The association between vote choice at the 2020 referendum and the retrospective foreseeability of the result is moderated by populist attitudes, resulting in increased foreseeability among more populist participants who had voted in favour of the reform (H3a) and conversely decreased foreseeability among more populist participants who had voted against the reform $(\mathrm{H} 3 b)$.

\section{THE CASE OF THE ITALIAN CONSTITUTIONAL REFERENDA}

In the present study, we analyzed the ITANES data collected before and after the 2016 and the 2020 referenda, in order to understand the individual and psychological characteristics of populist voters, and how they affected the outcomes of the two referenda, and voters' evaluation of them.

The 2016 and 2020 constitutional referenda were chosen for three key reasons.

First, the referenda were held away from major European, national, or local electoral competitions, and concerned matters outside the usual range of the electoral debate (e.g., parliamentary representation and legislative procedure). Therefore, we were able to test the impact of populist attitudes on political decision-making outside the scenarios where they have been typically investigated, which are often characterized by intense political campaigning, heightened salience of political and party identity, and a power imbalance between larger, traditional, and mainstream parties and smaller, upand-coming, and radical populist movements. 
Second, despite their atypicality, both referenda were political landmarks at the time they were held, raising them to the rank of "first order" elections (Reif \& Schmitt, 1980). In 2016, the constitutional reform championed by the then Prime Minister Matteo Renzi was rejected by a large majority of voters (59.1\%), an outcome that was interpreted as a sign of the declining popularity of Renzi and of his party (Ceccarini \& Bordignon, 2017), and the growing strength of populist opposition movements (De Blasio \& Sorice, 2019), in particular the Five Star Movement and the Lega Party, which would eventually form a parliamentary majority after the 2018 elections. The 2020 constitutional referendum was held in a further radically changed scenario. It was the first major election after the beginning of the COVID-19 pandemic (having been postponed due to the initial outbreak in the spring of the same year), and after the two main populist movements had parted ways, with the FiveStar Movement forming a new centre-left majority, and the Lega becoming the leading force of a reconstituted centre-right opposition. At this time, the proposal was approved by an even larger majority of voters (69.96\%) than those who had rejected the 2016 reform.

Third, the constitutional reforms of 2016 and 2020 reflected two different approaches to long-standing issues in the functioning of Italian political institutions, which may have had equally different appeal for populist (and non-populist) voters. The 2016 constitutional reform aimed at changing several elements of the executive and legislative systems, including the composition of the Senate, certain aspects of parliamentary procedure, the power balance between national and regional administrative levels. The implications of these changes were not easily accessible to all citizens, and discussion around the reform often revolved around complex technicalities of constitutional law. The 2020 constitutional reform, conversely, had a much more limited and straightforward aim, that is the proportional reduction of the number of elected representatives in the two legislative chambers (from 945 to 600). This had been a central issue in the populist agenda for decades, and one of the key points in the Five Star Movement's platform.

\section{METHOD}

\section{Participants}

We analyzed data from four waves of the ITANES nationwide panel survey. The surveys were conducted before and after the 2016 and 2020's constitutional referendums in Italy. The 2016 wave involved a representative sample of $N=3027$ Italian voters, the 2020 involved a sample of $N=3355$, of which $N=2041$ had participated to the 2016 waves.

\section{Measures}

Populist Attitudes. A short six-item scale measured participants' populist attitudes. The items, based on the Akkerman et al. (2014) scale, were the following: "Politicians must follow the citizens' will" (1); "Citizens and not politicians should take the most important political decisions" (2); "The differences that exist between politicians and the people are greater that the differences within the people" (3); "I would prefer being represented by a common person rather than by a professional politician" (4); "Making compromises in politics means selling off your own principles" (5), and "Politicians speak too much and do too little" (6). The items were meant to tap into the three main dimensions of populist attitudes postulated by Akkerman et al. (2014), namely popular sovereignty (items 1,2), the division between the people and the elite (items 3, 4), and Manichaeism (items 5, 6). Participants were asked to rate each statement on a scale ranging from 1 (Strongly agree) to 5 (Strongly disagree).

Political Orientation. Respondents were asked to position themselves on the left-right axis of the political spectrum: "When people talk about politics, they use the words "left" and "right" Here's a row of boxes that goes from left to right. Considering your political views, what box would you choose?". The possible answers were scored from 0 (Left) to 10 (Right), with the two further options "I don't know" and "None of these". A simple continuous index ranging from left to right was used in the main analyses, excluding participants who did not reveal their orientation. In an additional supplementary analysis reported in the Appendix (see Table A1), political orientation was recoded as a series of dummy variables representing participants on the extreme left (self-reported scores of 0-1), center-left (2-4), center (5), center-right (6-8), extreme right (9-10), and non-reported orientation (12-13).

Economic Evaluation. Participants were asked to evaluate the economic situation of their country: "According to you, the economic situation in Italy in the last year is..." and their family: "According to you, the economic situation of your family in the last year is...", using a scale ranging from 1 (Much better) to 5 (Much worse).

Political Efficacy. Two items assessed people's perception of internal political efficacy: "Sometimes politics seems so complicated that you don't understand what is going on", and external political efficacy: "People like me have no influence on what the government does". Par- 
ticipants had to report their agreement with each statement on a scale ranging from 1 (Strongly disagree) to 4 (Strongly agree).

Attitude towards the EU. One item asked participants to express their judgement on the EU: "According to you, the fact that Italy is part of the European Union is", with three possible answers ( $1=$ a good thing, $2=\mathrm{a}$ bad thing; 3 = neither a good nor a bad thing).

Attitude Towards Immigration. Participants were asked to position themselves on the issue of immigration: "Some people say we receive too many immigrants. Others say it's ok as it is right now. Others say we could easily welcome more of them. Where would you position your opinion?", on a 7 -point scale $(1=$ We receive too many immigrants; 7 = We could easily welcome more immigrants).

Conspiracy Beliefs. Participants were asked to rate the plausibility of 4 conspiracy theories, on a scale ranging from 0 (Not plausible) to 10 (Completely plausible). The items were the following: "The Moon landings never happened and their evidence was made up by NASA and the US Government"; "Vaccines destroy the immune system and expose it to several disease"; "The Stamina Therapy for neurodegenerative disease invented by Davide Vannoni has been boycotted by pharmaceutical companies"; "Aircraft spray chemical agents in the atmosphere as part of a clandestine programme led by political institutions".

Evaluation of the Constitutional Reforms. Participants were asked to evaluate the two constitutional reform proposals: "What is your judgement of the constitutional reform?", using a 11-point Likert scale ranging from 0 (Very negative) to 10 (Very positive).

Referendum Vote Choice. This item has been analysed both for the 2016 and 2020 referendum. Participants were asked to report their vote choice by two items, "What did you vote for in the 4 December Referendum?" in the 2016 post-electoral survey, and "What did you vote for in the 20-21 September Referendum?" in the 2020 post-electoral survey. The respondents had 4 possible answers: I voted yes; I voted no; I voted with a blank ballot; I did not vote.

Hindsight bias. In a section of the 2020 post-electoral survey, participants' opinion on the referendum results were assessed by one item asking participants "Before 21 September, many predictions were made about the result of the referendum. How much do you think it was foreseeable that 'yes' would win?". The answers were registered on a scale ranging from 0 (Not foreseeable at all) to 10 (Very foreseeable).

Sociodemographic Characteristics. Participants' basic sociodemographic characteristics (gender, age and level of education) were collected.

\section{RESULTS}

\section{Dimensional structure of populist attitudes}

As a preliminary step to our main analyses, we investigated the dimensional structure and reliability of the measure used in the ITANES panel survey. As described above, a shortened 6-item version of the scale originally proposed by Akkerman et al. (2014) was included in the survey, with 2 items investigating participants' attitudes along each of the three dimensions of popular sovereignty, the contraposition between the people and the elite, and Manichaeism. We performed confirmatory factor analyses for the postulated threedimensional model of populist attitudes and for a simplified one-dimensional model. Overall, the fit indexes of the two models were very similar (see Table 1), indicating that neither model was clearly superior to the other. The three dimensions were highly correlated with each other, $r(3259)>.500, p<.001$. Item saturations on the three dimensions were also similar (ranging from .580 to .876 for the sovereignty dimension; .642 to .733 for the anti-elitism dimension, and .515 to .711 for the Manichaeism dimension) to item saturations on the single factor (ranging from .498 to .870).

Based on Wuttke et al. (2020) discussion on the different scoring methods of populist attitudes scales, we computed two alternative scores reflecting compensatory and non-compensatory conceptual structures of populist attitudes. The first score was computed simply averaging the six items' scores into a single index. The second score was computed following the approach proposed by Goertz (2006), in two steps. First, we computed average indexes of the three dimensions of populist attitudes. Then we used the lowest of the three values as the global score. The resulting score represented the highest level of populism participants reported in all three dimensions simultaneously, thus resulting in significantly lower average scores, $M=2.01, S D=0.79$ vs. $M=3.46, S D=$ $0.78, t(2298)=45.26, p<.001$. The two indexes, however, were very strongly correlated, $r(2297)=.897, p<.001$. Based on these findings, in the main analyses we used the basic average index of the six items' scores as a simple unidimensional measure of populist attitudes (Cronbach's $\alpha=.77)$.

\section{Psychosocial antecedents of populist attitudes}

We entered the populist attitudes score as the dependent variable in a hierarchical linear regression model with six blocks of predictors: first, basic sociodemographic characteristics (gender, age, education), 
Table 1. Goodness-of-fit indexes for two alternative models of the populist attitudes measures.

\begin{tabular}{lcc}
\hline & Three-dimensional Model & Uni-dimensional Model \\
\hline$\chi^{2}(\mathrm{df})$ & $223.12^{\star}(6)$ & $240.91^{\star}(9)$ \\
RMSEA & .11 & .09 \\
CFI & .94 & .94 \\
TLI & .86 & .90 \\
SRMR & .04 & .04 \\
\hline
\end{tabular}

${ }^{*} p<.001$.

second, economic evaluations (familiar and national), third, perceived political efficacy (internal and external), fourth, nationalistic attitudes (towards the EU and immigration), fifth, political orientation, and finally the score on the conspiracy theory beliefs scale. Results from the full model are reported in the Appendix, Table A1. Economic evaluations were negatively associated with populist attitudes, but only weakly and non-significantly, $\beta s<.039$, ts $<1.56$, $p$ s $>.120$, thus not supporting our H1a. Both internal, $\beta=-.113, t=4.78, p<.001$, and external political efficacy, $\beta=-.092, t=3.89, p<.001$, were negatively associated with populist attitudes, in line with $\mathrm{H} 1 \mathrm{~b}$, as were attitudes towards the $\mathrm{EU}, \beta=-.067, t$ $=2.75, p=.006$, and especially towards immigration, $\beta$ $=-.314, t=10.97, p<.001$, providing support also to H1c and H1d. Finally, the hypothesized (H1e) association with political orientation was not significant, $\beta=.020, t$ $=0.71, p=.480$ (but see the Appendix and Table A1 for results of the analysis with recoded political orientation categories), and a positive and significant association with conspiracy theory beliefs was found, $\beta=.201, t=$ $8.05, p<.001$, thus supporting H1f ${ }^{1}$.

Populism as a predictor of vote choice in the 2016 and 2020 referendum

To assess whether populism would turn out to be a significant predictor of vote choice at the 2016 and 2020 referenda, we entered vote choice (coded 1 = yes; $0=$ no) in two separate logistic regression models, with three predictors entered in a stepwise fashion: The evaluation of the proposed constitutional reform, political orientation on the left-right axis, and populist attitudes scores. Participants' vote choice at the two referenda was

\footnotetext{
${ }^{1}$ The same analysis was performed using the alternative populist attitudes scores as the dependent variable. Results were overall similar, with the single but notable exception of the association between participants' attitude towards the EU and populist attitudes, which was no longer significant, $\beta=.038, t=1.45, p=.146$.
}

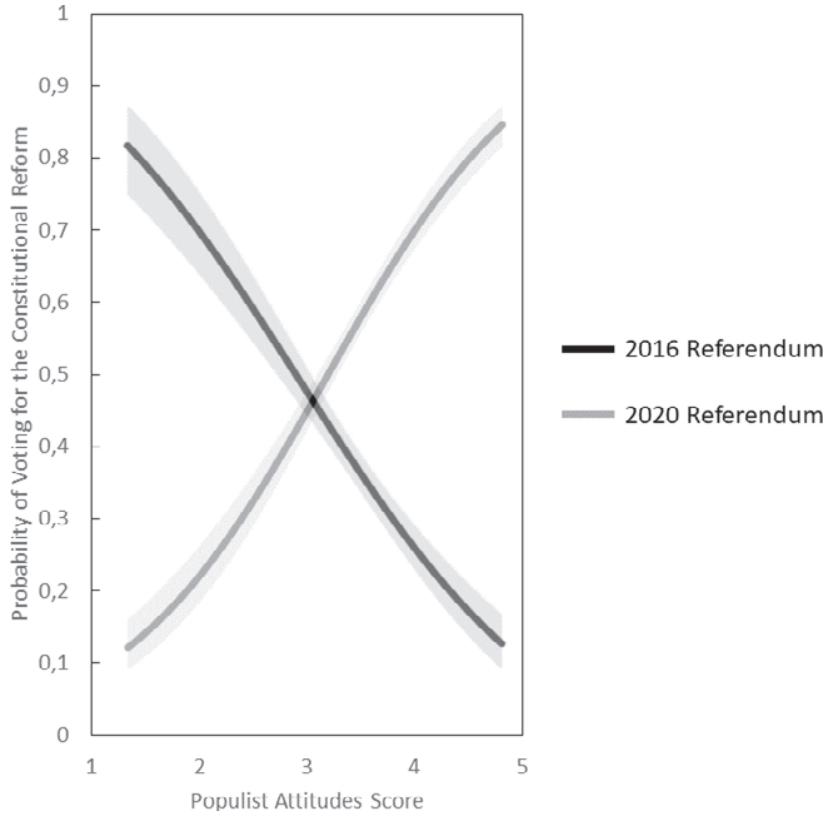

Figure 1. Probability of voting in favour of the 2016 and 2020 Constitutional reforms as a function of populist attitudes.

strongly predicted by their evaluation of the two constitutional reform proposals, and to a lesser degree by their political orientation (see Table A2 in the Appendix for the full model). Most importantly for the aims of the present study, populism was significantly and negatively associated with vote for the 2016 reform, $B=-.544$, $p$ $<.001, \operatorname{Exp}(B)=0.58$, and significantly and positively associated with vote for the 2020 reform, $B=.264$, $p=$ $.020, \operatorname{Exp}(B)=1.30$, thus providing support to both $\mathrm{H} 2 \mathrm{a}$ and $\mathrm{H} 2 \mathrm{~b}$ (Figure 1).

The results of the regression analyses therefore confirmed our hypothesis that populism would be a significant driver of vote choice in both the 2016 and 2020 referenda, providing voters with a potential cognitive shortcut when making a rather complex decision on whether to support or reject a constitutional reform. This process, quite common and accepted in the case of party affiliation and political orientation, can therefore be extended to populist attitudes, something that had not been empirically observed yet.

\section{Populist attitudes and hindsight bias}

The third aim of our study was to investigate whether populist attitudes would be associated with the tendency to incur in the hindsight bias, and specifically to report a biased, self-serving evaluation of the retrospective foreseeability of a referendum result. To test our 


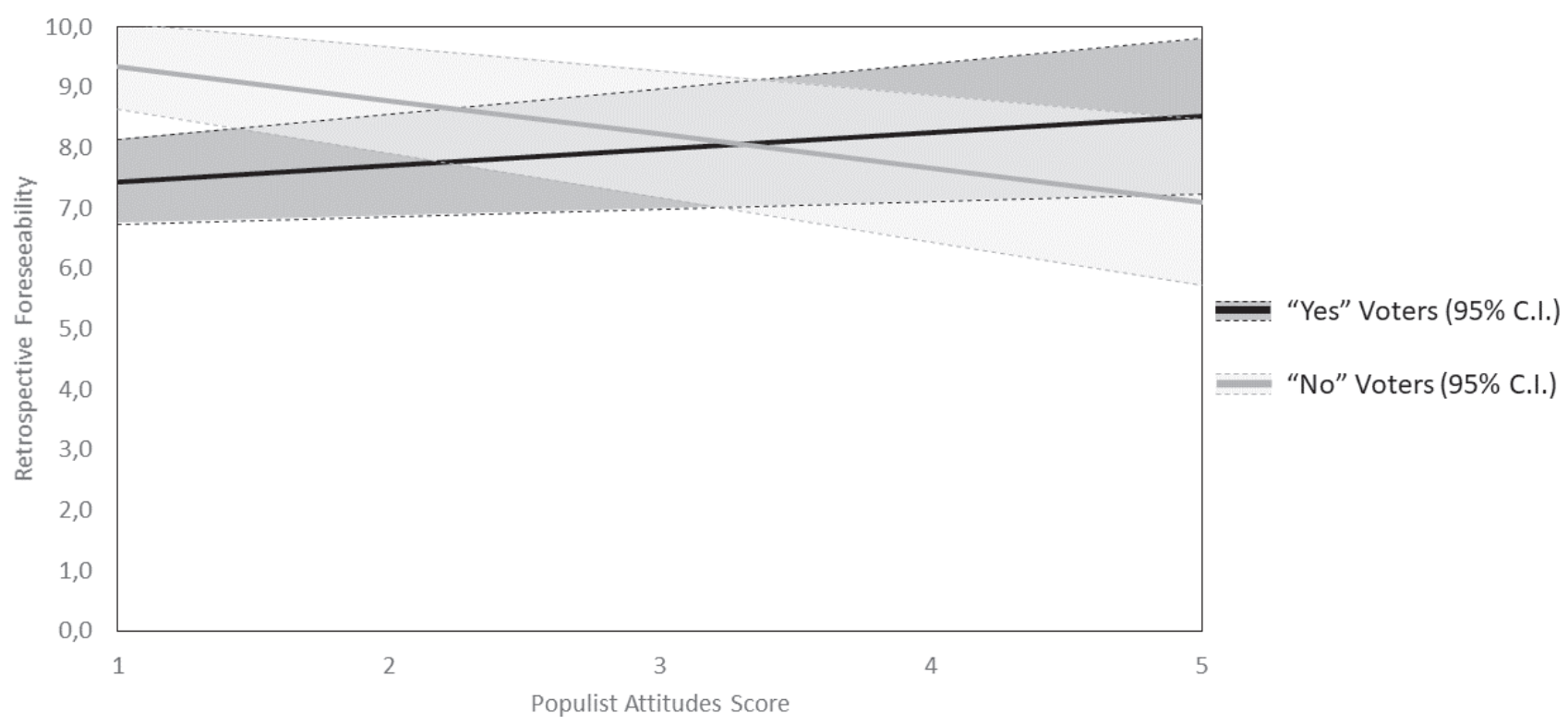

Figure 2. Retrospective foreseeability of the 2020 referendum outcome as a function of vote choice and populist attitudes

hypothesis, we regressed reported retrospective foreseeability of the 2020 referendum outcome on vote choice (coded 1 for "yes", -1 for "no"), populist attitudes scores, and the interaction between the two, using political orientation and the evaluation of the constitutional reform as additional covariates in the multiple regression model.

Results showed that vote choice did not have a significant effect on retrospective foreseeability, $B=-0.024, t=$ $0.34, p=.736$, whereas populist attitudes were negatively associated with it, $B=-0.188, t=2.87, p=.004$. The interaction term between vote choice and populist attitudes was also significant, $B=0.417, t=6.86, p<.001$. No significant effects of political orientation or of the evaluation of the constitutional reform emerged, $B s<0.031$, $t$ s $<1.43$, $p s>.154$. A follow-up analysis of the conditional effects of populist attitudes on retrospective foreseeability for participants who had voted in support or against of the constitutional reform showed the predicted opposing trends. Whereas among the supporters of the winning ("yes") side stronger populist attitudes were associated with higher retrospective foreseeability, $B=0.273, t=3.63$, $p$ $<.001$, as predicted by H3a, among supporters of the losing ("no") side stronger populist attitudes were associated with lower retrospective foreseeability, $B=-0.566, t$ $=6.69, p<.001$, as predicted by H3b. In other words, the more participants had strong populist attitudes, the more they tended to have biased, self-serving evaluations of the predictability of the referendum outcome. They reported it to be more predictable, when they personally agreed with the outcome, while they reported it to be less predictable, when they had originally hoped for a different outcome.

\section{DISCUSSION}

Our study investigated the role of populist attitudes in the 2016 and 2020 Italian constitutional referenda, taking an in-depth look at the psychosocial and political antecedents of populist attitudes, and at how such attitudes not only influence political behaviour (i.e., vote choice), but also bias voters' evaluation of political events, such as said referenda.

As to the first aim of our study, our analyses provided empirical support to most of the hypothesized associations between psychosocial and populist attitudes. Interestingly, political attitudes related with nationalism, and the attitude towards immigration in particular, were the strongest predictors of populism, whereas economic concerns was unrelated to it. This finding offers substantial evidence in favor of the "cultural backlash hypothesis" (Inglehart \& Norris, 2016) as compared to the "economic anxiety hypothesis" (Hernandez \& Kriesi, 2016), although the limited and specific geographic and temporal context in which our data were collected certainly calls for additional research in the future. Our findings confirm the idea that populism can be traced back to a multitude of factors that pertain not only to specific positions on political issues such as immigration and national sovereignty, but also to citizens' perception of control (or lack thereof) regarding political institutions, as evidenced by the negative association with political efficacy, as well as the way of thinking about political events, as evidenced by the positive association with belief in conspiracy theories (Enders \& Smallpage, 2019; 
van Proojen \& Douglas, 2018). Future research might further investigate these dimensions, and also explore how different measures of populism (Akkerman et al., 2014; Castanho Silva et al., 2018; Schulz et al., 2018) and different scoring methods (Wuttke et al., 2020) might provide a clearer picture of the relationship between this construct and its antecedents. The additional analyses we conducted on a slightly different index of populist attitudes (based on Wuttke et al., 2020) suggest that different methods may uncover some variability in the relative importance of specific political positions (regarding EU membership, in our case) in the formation of populist attitudes.

As to the impact of populist attitudes on vote choice at the two referenda, we found that they did play a role in participants' vote, once accounted for their evaluation of the respective constitutional reforms and political orientation. In particular, our findings suggest that voters may have resorted, to some extent, to a "populist heuristic" when deciding whether to support the two constitutional reforms. In particular, voters' pre-existing populist attitudes seem to have driven them away from the rather complex and technical reform proposal of 2016, and have boosted support of the simple and very specific proposal of 2020. These findings might contribute to the ever growing literature on voters' use of cognitive shortcuts, anchors, and heuristics in political decision-making (Lau, Kleinbert \& Ditonto, 2018), providing some insight on the intuitive rules used by populist voters.

Finally, our investigation of the cognitive underpinnings of populist attitudes provided some original and rather fascinating results. Analysing participants' bias in evaluating the foreseeability of election results, we found potential evidence of the cognitive factor connecting biased information processing, motivated reasoning and populist attitudes. In particular, our findings indicate that the stronger were participants' populist attitudes, the more likely they were to interpret the outcome of the referendum through the distorting lens of their expectations. More specifically, populist supporters of the constitutional reform saw the positive result of the referendum as more foreseeable than less populist fellow supporters, possibly reflecting their motivation to see the world as simple and orderly (Mark \& Mellor, 1991), and to emphasize the merit of their success. We found the opposite trend among those who voted against the constitutional reform, as the more populist ones were more likely to see their defeat as unforeseeable, partially shielding themselves from the negative repercussions on self-evaluation of having just lost an election (Pezzo \& Pezzo, 2007).

Our study has some relevant limitations due to its limited scope, as it is based on data from just two elec- tions in a single country, and the relative novelty of several investigated constructs, such as populist attitudes, belief in conspiracy theories, and the retrospective foreseeability component of the hindsight bias. In particular, longitudinal and comparative studies might help clarifying the role of populist attitudes in voting decision, by looking at different contexts and situations, such as different types of election (Garry, Marsch, \& Sinnott, 2005), and consider also the presence and relevance of partisan cues, and differences in media coverage of campaigns. As for the link between populist attitudes and the hindsight bias, these are among the first findings on this phenomenon in the political domain. Future studies might as well investigate it in other elections and contexts. Further research in more controlled, experimental scenarios might also help establishing a clear causal relationship between populist attitudes and this specific type of motivated reasoning. Nevertheless, these results might provide new and important insight on previously unexplored psychological differences among voters, and on how they influence the evaluation of relevant political events.

\section{REFERENCES}

Achen, C., \& Bartels, L. (2016). Democracy for realists: Holding up a mirror to the electorate. Juncture, 22(4), 269-275.

Akkerman, A., Mudde, C., \& Zaslove, A. (2014). How populist are the people? Measuring populist attitudes in voters. Comparative Political Studies, 47(9), 13241353.

Algan, Y., Guriev, S., Papaioannou, E., \& Passari, E. (2017). The European trust crisis and the rise of populism. Brookings Papers on Economic Activity, 2017(2), 309-400.

Bellucci, P. \& Serricchio, F. (2016). Europeismo, euroscetticismo e crisi economica. In D. Pasquinucci, \& L. Verzichelli (Eds.), Contro l'Europa: I diversi scetticismi verso l'integrazione europea (pp. 215-232). Bologna: Il Mulino.

Bertolotti, M. \& Catellani, P. (2021). Hindsight bias and electoral outcomes: Satisfaction counts more than winner-loser status. Social Cognition, 39, 201-224.

Blank, H., Fischer, V., \& Erdfelder, E. (2003). Hindsight bias in political elections. Memory, 11(4-5), 491504.

Castanho Silva, B., Vegetti, F., \& Littvay, L. (2017). The elite is up to something: Exploring the relation between populism and belief in conspiracy theories. Swiss Political Science Review, 23(4), 423-443. 
Catellani, P. (2020). Cognitive and Psychosocial Factors in Online Political Communication. Comunicazione Politica, 21(1), 75-86.

Ceccarini, L., \& Bordignon, F. (2017). Referendum on Renzi: The 2016 vote on the Italian constitutional revision. South European Society and Politics, 22(3), 281-302.

Cremonesi, C. (2019). Media messages' influence on populist attitudes. State of the art and insights from an experimental research on the Italian case. Italian Political Science, 14(1), 50-67.

Colombo, C., \& Kriesi, H. (2017). Party, policy-or both? Partisan-biased processing of policy arguments in direct democracy. Journal of Elections, Public Opinion and Parties, 27(3), 235-253.

De Angelis, A., Colombo, C., \& Morisi, D. (2020). Taking cues from the government: heuristic versus systematic processing in a constitutional referendum. West European Politics, 43(4), 845-868.

De Blasio, E., \& Sorice, M. (2019). The rise of populist parties in Italy: Techno-populism between neo-liberalism and direct democracy. In E. Hidalgo Tenorio, M.A. Benitez Castro, \& F. De Cesare (Eds.), Populist discourse: Critical approaches to contemporary (pp. 33-51). Routledge.

De Zavala, A. G., Cichocka, A., Eidelson, R., \& Jayawickreme, N. (2009). Collective narcissism and its social consequences. Journal of Personality and Social Psychology, 97(6), 1074-1096.

Douglas, K. M., Sutton, R. M., \& Cichocka, A. (2017). The psychology of conspiracy theories. Current Directions in Psychological Science, 26(6), 538-542.

Eatwell, R., \& Goodwin, M. (2018). National populism: The revolt against liberal democracy. Penguin UK.

Elchardus, M., \& Spruyt, B. (2012). Populisme en de zorg over de samenleving [Populism and the concerns over the society]. Sociologie, 8, 107-126

Elchardus, M., \& Spruyt, B. (2016). Populism, persistent republicanism and declinism: An empirical analysis of populism as a thin ideology. Government and Opposition, 51(1), 111-133.

Enders, A. M., \& Smallpage, S. M. (2019). Who are conspiracy theorists? A comprehensive approach to explaining conspiracy beliefs. Social Science Quarterly, 100(6), 2017-2032.

Federico, C. M., \& Malka, A. (2018). The contingent, contextual nature of the relationship between needs for security and certainty and political preferences: Evidence and implications. Political Psychology, 39, 3-48.

Fiedler, K. (2021). A non-populist perspective on populism in psychological science. In J.P. Forgas, W. Crano, \& K. Fiedler, The psychology of populism (pp. 174-194). Routledge.
Fischhoff, B. (1975). Hindsight is not equal to foresight: The effect of outcome knowledge on judgment under uncertainty. Journal of Experimental Psychology: Human perception and performance, 1(3), 288-299. https://doi.org/10.1037/0096-1523.1.3.288.

Flynn, D. J., Nyhan, B., \& Reifler, J. (2017). The nature and origins of misperceptions: Understanding false and unsupported beliefs about politics. Political Psychology, 38, 127-150.

Garry, J., Marsh, M., \& Sinnott, R. (2005). 'Secondorder'versus 'Issue-voting'Effects in EU Referendums: evidence from the Irish nice treaty referendums. European Union Politics, 6(2), 201-221.

Geurkink, B., Zaslove, A., Sluiter, R., \& Jacobs, K. (2020). Populist attitudes, political trust, and external political efficacy: Old wine in new bottles?. Political Studies, 68(1), 247-267.

Goertzel, T. (1994). Belief in conspiracy theories. Political Psychology, 15(4), 731-742.

Hameleers, M. (2020). They are selling themselves out to the enemy! The content and effects of populist conspiracy theories. International Journal of Public Opinion Research, 33(1), 38-56.

Hawkins, K. A. (2009). Is Chávez populist? Measuring populist discourse in comparative perspective. Comparative Political Studies, 42(8), 1040-1067.

Hawkins, K. A., Riding, S., \& Mudde, C. (2012). Measuring populist attitudes. Political Concepts Committee on Concepts and Methods Working Paper Series, 55, 1-35.

Hawkins, K. A., \& Rovira Kaltwasser, C. (2014). The populist specter in contemporary Chile. Paper presented at the 2014 Latin American Studies Association (LASA), Chicago, IL.

Hernández, E., \& Kriesi, H. (2016). The electoral consequences of the financial and economic crisis in Europe. European Journal of Political Research, 55(2), 203-224.

Inglehart, R. F., \& Norris, P. (2016). Trump, Brexit, and the rise of populism: Economic have-nots and cultural backlash. HKS Working Paper No. RWP16-026, July 29, 2016.

Jost, J. T. (2017). Ideological asymmetries and the essence of political psychology. Political psychology, 38(2), 167-208.

Jost, J. T., Hennes, E. P., \& Lavine, H. (2013). "Hot” political cognition: Its self-, group-, and system-serving purposes. In D. E. Carlston (Ed.), The Oxford handbook of social cognition (p.p 851-875). Oxford University Press.

Kahan, D.M. (2016). The Politically Motivated Reasoning Paradigm, Part 1: What Politically Motivated Reasoning Is and How to Measure It. In R.A. Scott, \& S.M. 
Kosslyn (Eds.), Emerging Trends in the Social and Behavioral Sciences.

Kruglanski, A. W., \& Webster, D. M. (1996). Motivated closing of the mind: "Seizing" and "freezing.". Psychological Review, 103(2), 263-283.

Lau, R. R., Kleinberg, M. S., \& Ditonto, T. M. (2018). Measuring voter decision strategies in political behavior and public opinion research. Public Opinion Quarterly, 82(S1), 911-936.

Lau, R. R., \& Redlawsk, D. P. (2001). Advantages and disadvantages of cognitive heuristics in political decision making. American Journal of Political Science, 951-971.

Leeper, T. J., \& Slothuus, R. (2014). Political parties, motivated reasoning, and public opinion formation. Political Psychology, 35, 129-156.

Lodge, M., \& Taber, C. S. (2013). The rationalizing voter. Cambridge University Press.

Louie, T. A. (1999). Decision makers' hindsight bias after receiving favorable and unfavorable feedback. Journal of Applied Psychology, 84(1), 29-41.

Louie, T. A., Curren, M. T., \& Harich, K. R. (2000). "I knew we would win": Hindsight bias for favorable and unfavorable team decision outcomes. Journal of Applied Psychology, 85(2), 264-272.

Lupia, A., McCubbins, M. D., \& Popkin, S. L. (2000). Beyond rationality: Reason and the study of politics. In A. Lupia, M.D. McCubbins, \& S.L. Popkin (Eds.), Elements of reason: Cognition, choice, and the bounds of rationality (pp. 1-20). Cambridge, UK: Cambridge University Press.

Marchlewska, M., Cichocka, A., Panayiotou, O., Castellanos, K., \& Batayneh, J. (2018). Populism as identity politics: Perceived in-group disadvantage, collective narcissism, and support for populism. Social Psychological and Personality Science, 9(2), 151-162.

Mark, M. M., \& Mellor, S. (1991). Effect of self-relevance of an event on hindsight bias: The foreseeability of a layoff. Journal of Applied Psychology, 76(4), 569-577.

Markman, K. D., \& Tetlock, P. E. (2000). 'I couldn't have known': Accountability, foreseeability and counterfactual denials of responsibility. British Journal of Social Psychology, 39(3), 313-325.

Mayer, L. C., Kaymak, E., \& Justice, J. W. (2000). Populism and the triumph of the politics of identity: The transformation of the Canadian party system. Nationalism and Ethnic Politics, 6(1), 72-102.

McGraw, A. P., \& Tetlock, P. E. (2005). Taboo trade-offs, relational framing, and the acceptability of exchanges. Journal of Consumer Psychology, 15(1), 2-15.

Mudde, C. (1999). The single-issue party thesis: Extreme right parties and the immigration issue. West European Politics, 22(3), 182-197.
Mudde, C. (2007). Populist radical right parties in Europe. Cambridge, UK: Cambridge University Press.

Mudde, C., \& Rovira Kaltwasser, C. (2013). Populism and leadership. In P. 't Hart \& Rhodes R.A.W. R. Rhodes (Eds.), Oxford Handbook of Political Leadership (pp. 493-512). Oxford, UK: Oxford University Press.

Oliver, J. E., \& Rahn, W. M. (2016). Rise of the Trumpenvolk: Populism in the 2016 Election. The Annals of the American Academy of Political and Social Science, 667(1), 189-206.

Passarelli, G., \& Tuorto, D. (2018). The Five Star Movement: Purely a matter of protest? The rise of a new party between political discontent and reasoned voting. Party Politics, 24(2), 129-140.

Pauwels, T. (2011). Measuring populism: A quantitative text analysis of party literature in Belgium. Journal of Elections, Public Opinion and Parties, 21(1), 97-119.

Pettigrew, T. F. (2016). In pursuit of three theories: Authoritarianism, relative deprivation, and intergroup contact. Annual Review of Psychology, 67, 1-21.

Pezzo, M. V., \& Pezzo, S. P. (2007). Making sense of failure: A motivated model of hindsight bias. Social Cognition, 25(1), 147-164.

Pezzo, M. V. (2011). Hindsight bias: A primer for motivational researchers. Social and Personality Psychology Compass, 5(9), 665-678.

Reif, K., \& Schmitt, H. (1980). Nine-second-order national elections: A conceptual framework for the analysis of European election results. European Journal of Political Research, 8(1), 3-44

Roese, N. J., \& Vohs, K. D. (2012). Hindsight bias. Perspectives on Psychological Science, 7(5), 411-426.

Rooduijn, M. (2018). What unites the voter bases of populist parties? Comparing the electorates of 15 populist parties. European Political Science Review, 10(3), 351-368.

Rooduijn, M., \& Burgoon, B. (2018). The paradox of well-being: do unfavorable socioeconomic and sociocultural contexts deepen or dampen radical left and right voting among the less well-off?. Comparative Political Studies, 51(13), 1720-1753.

Rooduijn, M., De Lange, S. L., \& Van der Brug, W. (2014). A populist Zeitgeist? Programmatic contagion by populist parties in Western Europe. Party Politics, 20(4), 563-575.

Rooduijn, M., \& Pauwels, T. (2011). Measuring populism: Comparing two methods of content analysis. West European Politics, 34(6), 1272-1283.

Rooduijn, M., Van Der Brug, W., \& De Lange, S. L. (2016). Expressing or fuelling discontent? The relationship between populist voting and political discontent. Electoral Studies, 43, 32-40. 
Rothwell, J. T., \& Diego-Rosell, P. (2016). Explaining nationalist political views: The case of Donald Trump. Available at SSRN: http://dx.doi.org/10.2139/ ssrn.2822059

Schulz, A., Müller, P., Schemer, C., Wirz, D. S., Wettstein, M., \& Wirth, W. (2018). Measuring populist attitudes on three dimensions. International Journal of Public Opinion Research, 30(2), 316-326.

Sedikides, C., \& Gregg, A. P. (2008). Self-enhancement: Food for thought. Perspectives on Psychological Science, 3(2), 102-116.

Spruyt, B., Keppens, G. \& van Droogenbroeck, F. (2016). Who supports populism and what attracts people to it? Political Research Quarterly, 69(2), 335-346.

Stanley, B. (2011). Populism, nationalism, or national populism? An analysis of Slovak voting behaviour at the 2010 parliamentary election. Communist and Post-Communist Studies, 44(4), 257-270.

Stephan, W.G., Ybarra, O., \& Morrison, K.R., (2016). Intergroup threat theory. In T.D. Nelson, (Ed.), Handbook of prejudice, stereotyping, and discrimination (pp. 255-278), New York: Psychology Press.

Taber, C. S., \& Lodge, M. (2006). Motivated skepticism in the evaluation of political beliefs. American Journal of Political Science, 50(3), 755-769.

Thompson, S. C., Armstrong, W., \& Thomas, C. (1998). Illusions of control, underestimations, and accuracy: a control heuristic explanation. Psychological bulletin, 123(2), 143-161.

Van der Brug, W. (2003). How the LPF fuelled discontent: Empirical tests of explanations of LPF support. Acta Politica, 38(1), 89-106.

van Prooijen, J. W., \& Douglas, K. M. (2018). Belief in conspiracy theories: Basic principles of an emerging research domain. European journal of social psychology, 48(7), 897-908.

Vasilopoulos, P., \& Jost, J. T. (2020). Psychological similarities and dissimilarities between left-wing and right-wing populists: Evidence from a nationally representative survey in France. Journal of Research in Personality, 88, 104004 https://doi.org/10.1016/j. jrp.2020.104004.

Walker, I., \& Pettigrew, T. F. (1984). Relative deprivation theory: An overview and conceptual critique. British Journal of Social Psychology, 23(4), 301-310.

Wuttke, A., Schimpf, C., \& Schoen, H. (2020). When the whole is greater than the sum of its parts: On the conceptualization and measurement of populist attitudes and other multidimensional constructs. American Political Science Review, 114(2), 356-374. 


\section{APPENDIX}

Table A1. Multiple linear regression model of populist attitudes.

\begin{tabular}{|c|c|c|c|c|c|c|c|}
\hline & \multirow{2}{*}{$B$} & \multirow{2}{*}{ SE } & \multirow{2}{*}{$\beta$} & \multirow{2}{*}{$t$} & \multirow{2}{*}{$p$} & \multicolumn{2}{|c|}{$95 \% \mathrm{CI}$} \\
\hline & & & & & & LL & UL \\
\hline (Constant) & 4.37 & .157 & & 27.834 & .000 & 4.058 & 4.673 \\
\hline Gender & 0.03 & .036 & .021 & 0.931 & .352 & -0.037 & 0.105 \\
\hline Age & -0.01 & .012 & -.005 & 0.202 & .840 & -0.026 & 0.021 \\
\hline Education & -0.03 & .008 & -.096 & 3.970 & .000 & -0.045 & -0.015 \\
\hline National Economic Evaluation & -0.03 & .025 & -.030 & 1.221 & .222 & -0.078 & 0.018 \\
\hline Family Economic Evaluation & 0.01 & .027 & .004 & 0.164 & .869 & -0.048 & 0.057 \\
\hline Internal Political Efficacy & -0.10 & .023 & -.106 & 4.318 & .000 & -0.144 & -0.054 \\
\hline External Political Efficacy & -0.12 & .022 & -.126 & 5.264 & .000 & -0.159 & -0.073 \\
\hline EU Attitude & -0.06 & .024 & -.064 & 2.574 & .010 & -0.109 & -0.015 \\
\hline Immigration Attitude & -0.12 & .011 & -.309 & 10.688 & .000 & -0.140 & -0.096 \\
\hline \multicolumn{8}{|l|}{ Political Orientation } \\
\hline Extreme Left & 0.15 & .064 & .059 & 2.422 & .016 & 0.029 & 0.280 \\
\hline Center & 0.16 & .065 & .058 & 2.378 & .018 & 0.027 & 0.282 \\
\hline Center-Right & 0.03 & .053 & .019 & 0.640 & .522 & -0.071 & 0.139 \\
\hline Extreme Right & 0.21 & .073 & .081 & 2.924 & .004 & 0.070 & 0.357 \\
\hline Non-reported & 0.17 & .067 & .066 & 2.523 & .012 & 0.037 & 0.298 \\
\hline Conspiracy Theory Beliefs & 0.07 & .009 & .204 & 8.116 & .000 & 0.053 & 0.087 \\
\hline
\end{tabular}

Note: an alternative indicator of political orientation was used in this analysis, as a series of dummy variables representing categorial political orientations (extreme left, center, center-right, extreme right, and non-reported) were entered in the model, with the numerically largest category (center-left orientation) as reference. Results showed that participants in the extreme left and extreme right categories were had stronger populist attitudes than those in the center-left category, as did those in the non-reported political orientation category. Unexpectedly, also participants in the center category reported having stronger populist attitudes, whereas no difference was found with participants in the center-right category.

Table A2. Logistic regression models of vote choice in the 2016 and 2020 referenda.

\begin{tabular}{|c|c|c|c|c|c|c|c|}
\hline & & \multicolumn{3}{|c|}{2016} & \multicolumn{3}{|c|}{2020} \\
\hline & & $B$ & $\operatorname{Exp}(B)$ & $p$ & $B$ & $\operatorname{Exp}(B)$ & $p$ \\
\hline \multirow[t]{3}{*}{1} & (Constant) & -2.992 & .050 & .000 & -4.876 & .008 & .000 \\
\hline & Evaluation of the reform & .433 & 1.542 & .000 & .818 & 2.267 & .000 \\
\hline & $R^{2}$ & \multicolumn{2}{|c|}{.398} & .000 & \multicolumn{2}{|c|}{.703} & .000 \\
\hline \multirow[t]{4}{*}{2} & (Constant) & -2.026 & .132 & .000 & -4.955 & .007 & .000 \\
\hline & Evaluation of the reform & .473 & 1.606 & .000 & .812 & 2.252 & .000 \\
\hline & Political orientation & -.184 & 1.203 & .000 & .008 & 1.008 & .955 \\
\hline & $R^{2}$ & \multicolumn{2}{|c|}{.449} & .000 & \multicolumn{2}{|c|}{.706} & .004 \\
\hline \multirow[t]{5}{*}{3} & (Constant) & -.460 & .632 & .170 & -5.492 & .004 & .000 \\
\hline & Evaluation of the reform & .475 & .1 .609 & .000 & .796 & 2.216 & .000 \\
\hline & Political orientation & -.175 & .840 & .000 & -.010 & .990 & .733 \\
\hline & Populism & -.544 & 580 & .000 & .221 & 1.248 & .039 \\
\hline & $R^{2}$ & \multicolumn{2}{|c|}{.470} & .000 & \multicolumn{2}{|c|}{.707} & .039 \\
\hline
\end{tabular}

